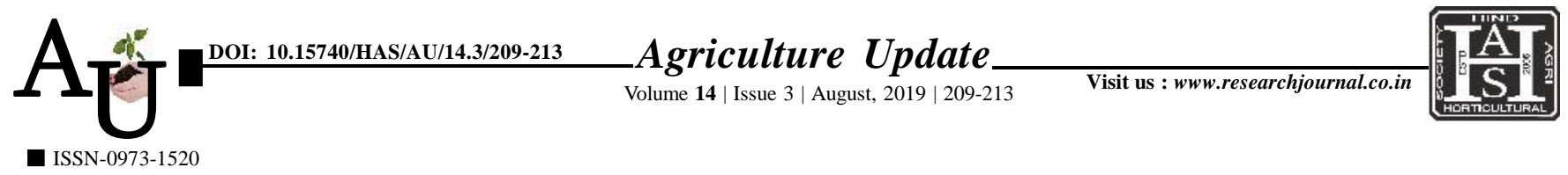

\title{
Reserkch Article: Perception of tribal farmers about front line demonstration
}

\author{
a.H. Lade, A.N. Deshmukh, S.B. Khodake, V.N. Suryvanshi and S.A. Deshmukh
}

Article Chronicle : Received :

04.06.2019;

Revised :

03.07.2019;

Accepted :

13.07.2019

\section{KEY WordS :}

Perception, Tribal farmers, KVK, Front line demonstration, Chikhaldara, Dharni
SUMMARY : The present study was conducted in Amravati district of Vidarbha region of Maharashtra state. The study "Perception of tribal farmers about front line demonstration" was conducted in Chikaldara and Dharni talukas of Amravati district, 80 respondents (tribal farmers) were purposively selected for study. The data were collected by personal interview method with the help of structured interview schedule. The data were tabulated, analyzed and interpreted. The findings of the study revealed that the majority of tribal farmers were having middle age group of 35 to 55 years, education upto high school level, medium level farming experience, marginal size of land holding ( 0.01 to $1.00 \mathrm{ha}$ ), low level training received and medium level annual income 50001 Rs. to 1,00,000 Rs. However, the observation also found that most of the respondents were possessed medium level social participation, medium level extension contact, medium level achievement motivation and medium level economic motivation. Majority of the respondents were interested in front line demonstration programme of Bengal gram and soybean. The significant variables include achievement motivation and economic motivation found the positive and significant level of probability 0.01 with perception level. The variable viz., training received, social participation and extension contact found positive and significant at 0.05 level of probability with perception level. The variable age, education, farming experience, land holding and annual income found non-significant relationship with perception level.

How to cite this article : Lade, A.H., Deshmukh, A.N., Khodake, S.B., Suryvanshi, V.N. and Deshmukh, S.A. (2019). Perception of tribal farmers about front line demonstration. Agric. Update, 14(3): 209-213; DOI : 10.15740/HAS/AU/14.3/209-213. Copyright@ 2019: Hind Agri-Horticultural Society.
Author for correspondence :

\section{A.N. Deshmukh}

Department of Extension Education, Shri Shivaji

Agriculture College,

Amravati (M.S.) India

Email: abhaydeshmukh

40@ rediffmail.com

See end of the article for

authors' affiliations 